\title{
Modeling protein-peptide interactions using protein fragments: fitting the pieces?
}

Peter Vanhee ${ }^{1,2^{*}}$, Francois Stricher ${ }^{3}$, Lies Baeten ${ }^{1,2}$, Erik Verschueren ${ }^{3}$, Luis Serrano ${ }^{3,4}$, Frederic Rousseau ${ }^{1,2}$, Joost Schymkowitz ${ }^{1,2}$

From Sixth International Society for Computational Biology (ISCB) Student Council Symposium Boston, MA, USA. 9 July 2010

An estimated $15-40 \%$ of all interactions in the cell are mediated through protein-peptide interactions [1,2] meaning that, at the most extreme, nearly every protein is affected either directly or indirectly by peptide-binding events.

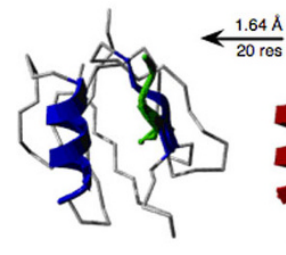

$1 w 9 q B S$

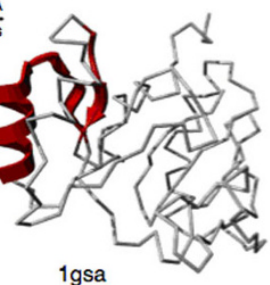

1 1gsa

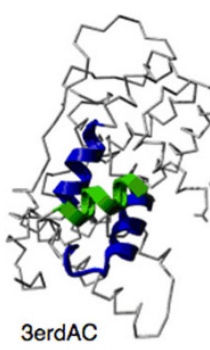

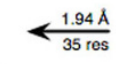
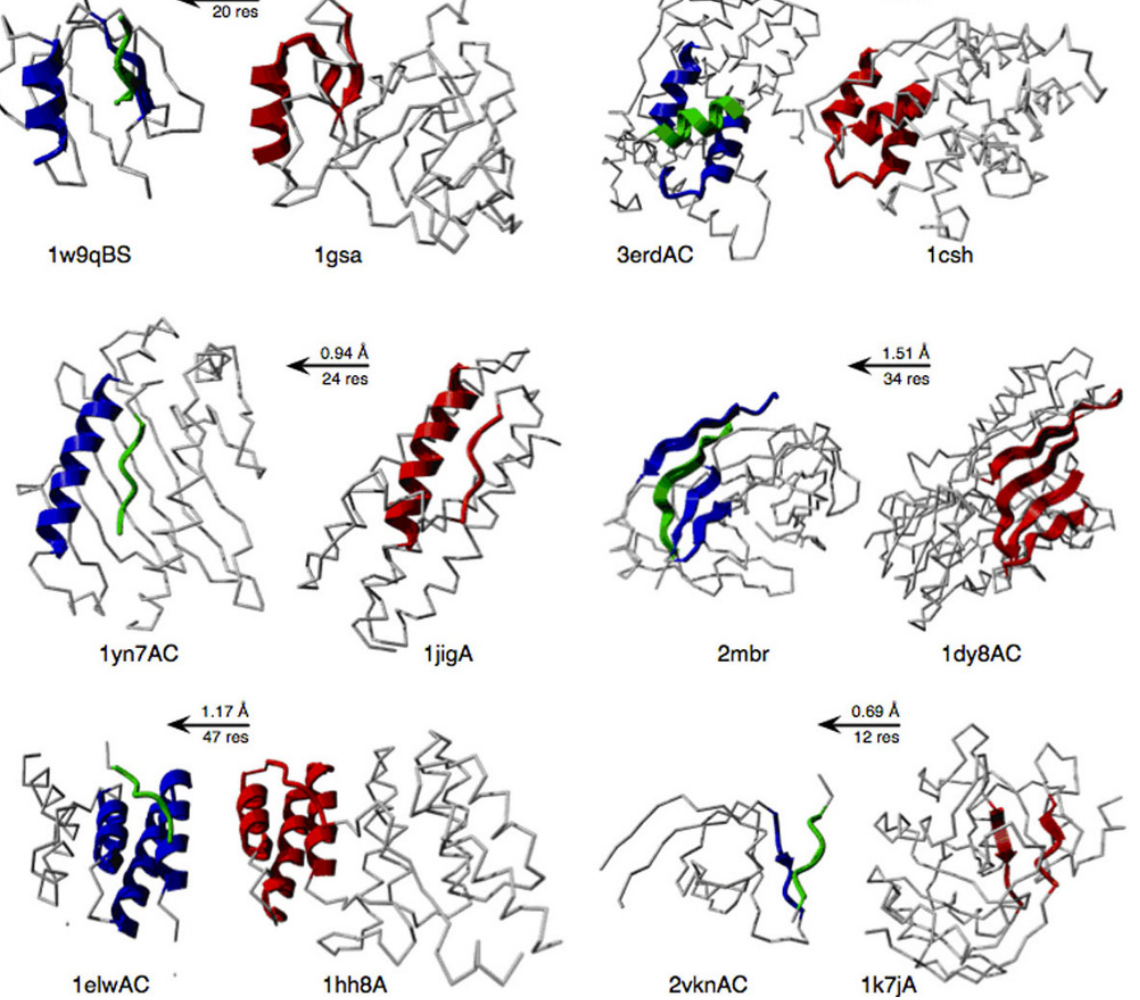

Figure 1 Relation between intermolecular protein-peptide interface architectures (blue for receptor, green for peptide ligand) and intramolecular protein architectures from our database of monomeric proteins, BriX (red) [4].

\footnotetext{
* Correspondence: peter.vanhee@switch.vib-vub.be

${ }^{1}$ VIB SWITCH laboratory, Pleinlaan 2, 1050 Brussels, Belgium

Full list of author information is available at the end of the article
} 
We compared the modes of interaction between protein-peptide interfaces and those observed within monomeric proteins and found surprisingly little differences [3]. Over $65 \%$ of 731 protein-peptide interfaces could be reconstructed within $1 \AA$ RMSD using solely fragment interactions occurring in monomeric proteins, using our fragment database BriX containing over 1000 non-redundant protein structures [4]. Interestingly, more than $80 \%$ of interacting fragments used in reconstructing a protein-peptide binding site were obtained from monomeric proteins of an entirely different structural classification, with an average sequence identity below $15 \%$. Nevertheless, geometric properties perfectly match the interaction patterns observed within monomeric proteins (see Figure 1), suggesting that our fragment interaction approach might provide an alternative to homology modelling.

We show the usefulness of our method by redesigning the interaction scaffold of nine protein-peptide complexes, for which five of the peptides can be modelled to within $1 \AA$ RMSD of the original peptide position.

These data suggest that the wealth of structural data on monomeric proteins could be harvested to model proteinpeptide interactions and, more importantly, that sequence homology is no prerequisite. In addition, we have made our dataset of 505 non-redundant protein-peptide complexes from 1431 entries in the PDB available at http://pepx.switchlab.org [5] and the BriX database at http://brix.crg.es [6].

\footnotetext{
Author details

${ }^{1}$ VIB SWITCH laboratory, Pleinlaan 2, 1050 Brussels, Belgium. ${ }^{2}$ Vrije Universiteit Brussel, Pleinlaan 2, 1050 Brussels, Belgium. ${ }^{3}$ EMBL-CRG Systems Biology Unit, CRG-Centre de Regulacio Genomica, Dr. Aiguader 88, 08003 Barcelona, Spain. ${ }^{4}$ ICREA. Institucio Catala de Recerca i Estudis Avancats. Passeig Lluís Companys, 2308010 Barcelona, Spain.
}

Published: 7 December 2010

\section{References}

1. Neduva V, Linding R, Su-Angrand I, Stark A, de Masi F, Gibson TJ, Lewis J, Serrano L, Russell RB: Systematic discovery of new recognition peptides mediating protein interaction networks. PLoS Biol 2005, 3(12):e405.

2. Petsalaki E, Russell RB: Peptide-mediated interactions in biological systems: new discoveries and applications. Curr Opin Biotechnol 2008, 19(4):344-350

3. Vanhee $P$, Stricher $F$, Baeten $L$, Verschueren $E$, Lenaerts $T$, Serrano $L$, Rousseau F, Schymkowitz J: Protein-Peptide Interactions Adopt the Same Structural Motifs as Monomeric Protein Folds. Structure 2009, 17(8):1128-1136

4. Baeten L, Reumers J, Tur V, Stricher F, Lenaerts T, Serrano L, Rousseau F, Schymkowitz J: Reconstruction of protein backbones from the BriX collection of canonical protein fragments. PLoS Comput Biol 2008, 4(5) e1000083.

5. Vanhee P, Reumers J, Stricher F, Baeten L, Serrano L, Schymkowitz J, Rousseau F: PepX: a structural database of non-redundant protein- peptide complexes. Nucleic Acids Research 2010, 38(Database issue): D545-551.

6. Vanhee $P$, Verschueren E, Stricher F, Baeten L, Serrano L, Schymkowitz J, Rousseau F: BriX: a database of protein building blocks for structural analysis, modeling and design. Nucleic Acids Research. Nucleic Acids Research 2010.

doi:10.1186/1471-2105-11-S10-O1

Cite this article as: Vanhee et al:: Modeling protein-peptide interactions using protein fragments: fitting the pieces? BMC Bioinformatics 201011 (Suppl 10):01.

\section{Submit your next manuscript to BioMed Central and take full advantage of:}

- Convenient online submission

- Thorough peer review

- No space constraints or color figure charges

- Immediate publication on acceptance

- Inclusion in PubMed, CAS, Scopus and Google Scholar

- Research which is freely available for redistribution

Submit your manuscript at www.biomedcentral.com/submit 